\title{
ERRATUM
}

\section{Erratum to: Operating behavior and performance of oil-lubricated plastic gears}

\section{M. Illenberger ${ }^{1}\left(\mathbb{D} \cdot\right.$ T. $^{\text {Tobie }}{ }^{1} \cdot$ K. Stahl $^{1}$}

Published online: 13 October 2021

(c) The Author(s) 2021

\section{Erratum to:}

\section{Forsch Ingenieurwes 2021}

https://doi.org/10.1007/s10010-021-00513-7

The unreinforced plastic gear indicates a minimum lubricant film thickness $\mathrm{h}_{\min }=0.39 \mu \mathrm{m}$ and a specific lubricant film thickness of $\lambda=1.6$ for the herein investigated operating conditions. The fiber reinforced variant, however, exhibits a minimum lubricant film thickness $h_{\min }=0.28 \mu \mathrm{m}$ and a specific lubricant film thickness of $\lambda=0.6$. Due to the higher roughness and the resulting low specific lubricant film thickness, the carbon fiber reinforced test gears may be more sensitive to wear in operation than the nonreinforced variants of lower roughness.

The original article has been corrected.
The online version of the original article can be found under https://doi.org/10.1007/s10010-021-00513-7

C. M. Illenberger

illenberger@fzg.mw.tum.de

1 Gear Research Centre (FZG), Technical University of Munich (TUM), Munich, Germany
Open Access This article is licensed under a Creative Commons Attribution 4.0 International License, which permits use, sharing, adaptation, distribution and reproduction in any medium or format, as long as you give appropriate credit to the original author(s) and the source, provide a link to the Creative Commons licence, and indicate if changes were made. The images or other third party material in this article are included in the article's Creative Commons licence, unless indicated otherwise in a credit line to the material. If material is not included in the article's Creative Commons licence and your intended use is not permitted by statutory regulation or exceeds the permitted use, you will need to obtain permission directly from the copyright holder. To view a copy of this licence, visit http://creativecommons.org/licenses/by/4. $0 /$. 